\title{
THE AVAILABILITY OF EDUCATED HUMAN CAPITAL IN REGIONS AND THE DEVELOPMENT OF SMALL AND MEDI- UM-SIZED ENTERPRISES
}

\author{
Michal HRIVNÁK \\ Department of Regional and Rural Development, Faculty of European Studies and \\ Regional Development, Slovak University of Agriculture

\section{Peter MORITZ} \\ Department of Regional and Rural Development, Faculty of European Studies and \\ Regional Development, Slovak University of Agriculture
}

Received: 29. April 2021 Reviewed: 17. June 2021 Accepted: 30. June 2021

\begin{abstract}
Along with globalization and rapid technological change, the importance of small and medium-sized enterprises, economic growth and the growth of competitiveness of regional economies are constantly growing. The development of small and medium-sized enterprises requires access to intellectual capital, in which the critical role of human capital and educated human capital can be recognized. The aim of this empirical study is to evaluate the impact of changes in the distribution of educated human capital at the level of regional economies in the country on the growth of small and medium sized entrepreneurship dynamics, using a panel regression. The results of the study confirm the fundamental impact of educated human capital on the development of small and medium-sized enterprises and, in particular, the positive impact of the production of university graduates on the development of SMEs in the regions in which they are allocated.
\end{abstract}

Keywords: intellectual capital, human capital, small and medium entrepreneurship

JEL Classification: J24, L26, O34

\section{Introduction}

In the early 1980s, a new theory of economic growth was developed which, unlike the classical one (labour productivity is considered an exogenous factor that depends on the labour and physical capital ratio and other factors) emphasizes the importance of education and innovation (elements of human capital) for long-term economic growth (Pelinescu, 2015). Intellectual capital is the most important component of pro- 
ductive assets of venture operating in a post-industrial information society (Zhuravlev et al., 2018). This type of capital is included in the intangible assets of the company, which, although not included in the financial reports of the company, but represents a large part of the market value of an enterprise (Manzari et al., 2012). In addition to relational and structural capital, human capital is included into intellectual capital (Wall, 2005, Tai \& Chen, 2009; Martinez-Torres, 2006). As an economic concept, we can understand human capital from both the microeconomic and macroeconomic perspective. While from the point of view of microeconomics it is perceived as a carrier of venture management, from the macroeconomic point of view it is understood as one of the basic production factors (Kucharčíková, 2011). The level or quality of human capital can be measured by the level of education, abilities and skills, the degree of productivity, or the experiences of individuals (Schultz, 1979). New theories of economic growth characterize human capital as a sum of innate and acquired abilities, knowledge and experience of the individual (Kucharčíková, 2011).

Human capital is one of the basic tools for gaining access to knowledge (Brassey 1872), especially tacit knowledge rooted in the unique experiences and abilities of the individual (Calcagnini, 2015). An educated human capital mediating access to knowledge is a prerequisite for the competitiveness and growth of a company's productivity, it can be a source of production of new ideas, approaches and innovations (Zhuravlev et al., 2018). A number of studies have therefore already confirmed that there is a link between human capital growth and the formation of enterprises, especially small and medium-sized enterprises (SMEs), which are key innovators in national and regional economies (Carmeli and Schaubroeck, 2005). As increasing the dynamics of small and medium-sized enterprises is a critical prerequisite for technological growth in the economy (Laperche \& Liu, 2013), our intention in this empirical study is to contribute to the understanding of the patterns of formation of small and medium sized enterprises. The impact of the availability of quality human capital on the formation of small and medium-sized enterprises will be measured at the LAU1 level by the growth of educated people in regions due to inter-regional migration, and the production of new human capital by universities at regional level.

\section{Theoretical background}

A wide variety of empirical studies document the undeniable role of educated human capital for economic growth (Lucas, 1988; Barro, 1991; Florax, 1992; Herbst \& Rok, 2013).

According to neoclassical economic theories, human capital influences economic growth through labour productivity and through the influence on the so-called overall factor productivity. Unlike the original Sollow model (1956), which assumes that every employee in the economy is identical in terms of productivity, Lucas (1988) considers human capital to be an individual aspect of each "worker." In Lucas's model, therefore, GDP per capita growth is equal to the rate of human capital accumulation. The first contribution to the study of the relationship between human capital and economic growth was a study by Mankiw and Romero (1992), who demonstrated on data between 1960-1985 that a 10\% increase in human capital in the economy would lead to an increase in GDP per capita between 6 and 7\% to 7.6\% (these results were later confirmed by Bernanke \& Gurkaynak, 2001). Later economic literature already perceives the relationship between human capital and technological growth, as human capital is beginning to be perceived at the turn of the millennium as a source or transmitter of innovation processes (Herbst \& Rok, 2013).

The most well-known empirical study that examined the impact of the initial 
educational level of human capital on subsequent economic growth is the contribution of Barro (1999). The data for more than 100 countries around the world for the years 1960-1995 were available for study. Barro found that a global increase in the average length of population studying by one year would lead to a consequent increase in economic growth of $0.7 \%$. Later, Barro and Sala-i-Martin (2004) examined this effect through primary school attendance rates and found that as the scholarization rate increased by $10 \%$, the average annual growth increased by $0.27 \%$.

Part of the literature after 2000, especially in Europe, has taken a spatially disaggregated approach due to the growing importance of regional economies. An example of such a study is e.g. Badinger and Tondl (2002), who examined the factors of economic growth in 128 European NUTS I regions in the 1990s. They have shown that both physical and human capital influence regional economic growth, but emphasized that only highly educated human capital had had a significant impact. According to their results, an increase in the volume of human capital with a university degree of $10 \%$ will lead to an increase in the economic growth rate by $1 \%$. The spatial aspect was included by Lesage and Fischer (2008), who confirmed that educated human capital not only affects regional economic growth, but also has a spatial spill-over effects. Higher economic growth was recorded in regions adjacent to those that produce a large amount of educated human capital.

Much of the studies that have investigated the migration of educated human capital focus on a phenomenon that has come to be known as "brain drain". These studies have provided insights into the effects of the emigration of quality human capital, which generally tends to migrate from less developed to more developed regions, exacerbating development disparities between countries and regions (Ciriaci, 2009). Older studies, almost all of which have addressed the issue of brain drain in terms of international migration, confirm that the mobility of educated human capital significantly impairs economic growth in less developed countries (e.g. Grubel \& Scott, 1966; Kwok \& Leland, 1982). The highest rates of migration of educated human capital to more developed regions were recorded in a later study by Frédéric and Marfouk (2006) in the Caribbean, Central America, East and South Asia, and Central and East Africa. The phenomenon of brain drain describes, of course, very asymmetric flows of human capital. In addition to the model we described above, the authors recognize two other types of migration of educated human capital. The two-way flows of educated human capital between spatial units that bring benefits in the form of knowledge exchange are referred to as "brain exchange" (Giannoccolo, 2006). Scientific studies also describe situations referred to as "brain waste", where educated human capital leaves a less developed region in order to perform menial work in a more developed region. Kaczmarczyk (2010) cites as a negative example of this trend in Europe the migration of educated Poles for menial work to the United Kingdom since the 1990s.

On the macroeconomic level, we have sufficient evidence, that growth in the level of quality of human capital is accompanied with economic growth (Anaduaka, 2014; Ogunleye, 2017). We also have solid evidence that the production of educated human capital by universities increases the dynamics of business in the regions in which the universities are located (Florax \& Folmer, 1992; Varga 1997; Audretsch \& Feldman, 2004; Astebro et al. 2012; Doms et al. 2010).

However, the focus of our attention is more on the issue of migration of educated human capital within the regions of the country. Inter-regional migration takes place mainly due to urban-rural migration (Liu, 2011). While mainly elite talent is able to overcome long distances, ordinary educated human capital migrates between regions within a country with a high frequency, which also affects business formation 
and growth (Eigbiremolen \& Anaduaka, 2014; Ogunleye et al. 2017). Entrepreneurship is a local event (Audretsch, et al., 2010); therefore, empirical studies have confirmed the influence of the parameters of the business environment in the locality on increasing the dynamics of migration (Dahl \& Sorenson, 2009; Hanson, 2003).

Here, however, we come to a gap in knowledge to which we would like to contribute. In the current literature on the topic, we still lack a debate on the impact of interregional migration on business formation in regional economies (Naudé et al. 2017; Thomas \& Impken, 2018), while there is still a lack of studies that take into account the importance of spatial relationships in clarifying the importance of quality human capital migration on entrepreneurship. Studies that would have data on the migration frequency of the educated at lower spatial levels are also very sporadic. Therefore, our intention is to contribute to the understanding of the importance of human capital for business development, by assessing the impact of production and migration of the educated on the increase of business activity dynamics at the regional level in the post-socialist economy.

\section{Material and methods}

The aim of the empirical study is to evaluate the impact of changes in the structure and availability of educated human capital in regions on the formation of small and medium-sized enterprises in the conditions of the Slovak Republic. We formulate the following scientific hypotheses, that arise from the literature concerning the impacts of migration patterns on the formation of SMEs (Naudé et al. 2017; Thomas \& Impken, 2018), while our intention is also to check, whether in conditions of less excellent universities compared to those in western countries, roll-out of new educated human capital contribute to business formation (Astebro et al. 2012; Doms et al. 2010):

- H1: the inflow of educated human capital into regions has a positive effect on the dynamics of the formation of small and medium-sized enterprises in the region

- H2: the production of university graduates in a region (t-1), positively influences the dynamics of the formation of small and medium-sized enterprises in the region

We propose the variable numgrad to be time-lagged, as an effect of graduates roll-out is not expected to impact entrepreneurship in the year of graduation (Doms et al. 2010). A secondary data at the spatial level LAU1 (districts) are used for statistical modelling, which we obtained from various sources - data on the number of small and medium-sized companies in individual years at the level of Slovak districts were constructed using the Register of Institutional Units in the Slovak Republic (Elis database), migration rates of the educated population were obtained from individual editions of the Yearbook of Slovak Regions and data on the production of graduates of academic institutions come from the CVTI (Centre for scientific and technical information) database, while the processing of specific frequencies of graduates rolled-out in regions were performed manually, based on information about individual faculties in Slovakia. Data on the remaining control variables came either from the databases of the Statistical Office of Slovak Republic or the Register of Institutional Units in the Slovak Republic. The spatial level LAU1 was chosen due to the spatial dimensions and the need to examine interregional flows at a lower spatial level, but also due to the need for a sufficient number of observations for the panel model. 
In Table 1 we can see an overview of the variables of our panel model. As control variables, we chose the frequency of business services in region, the number of patents and utility models registered by private sector actors in the region, the presence of incubators, the availability of counselling, population density to control agglomeration effects, the share of foreign companies on entrepreneurship in region as a significant source of knowledge and exogenous development and the level of the average nominal monthly wage.

Table 1 Specification of variables in the panel model

\begin{tabular}{|l|l|l|}
\hline \multicolumn{1}{|c|}{ variable } & \multicolumn{1}{c|}{ description } & type \\
\hline SMEs & number of SMEs in district $\mathrm{i}$, in year $\mathrm{t}$ & continuous \\
\hline imigeduc & number of immigrants with completed master degree in district $\mathrm{i}$, in year $\mathrm{t}$ & continuous \\
\hline numgrad & number of university graduates in district $\mathrm{i}$, in year $\mathrm{t}-1$ & continuous \\
\hline busservices & frequency of business services in district $\mathrm{i}$, in year $\mathrm{t}$ & continuous \\
\hline inov & number of patents and utility models of private ventures in district $\mathrm{i}$, in year $\mathrm{t}$ & continuous \\
\hline incub & presence of incubators (yes / no) in district $\mathrm{i}$, in year $\mathrm{t}$ & ordinal \\
\hline counselling & number of counselling institutional units in district $\mathrm{i}$, in year $\mathrm{t}$ & continuous \\
\hline popdens & population density per built-up area in district $\mathrm{i}$, in year $\mathrm{t}$ & continuous \\
\hline foreign & share of foreign-owned companies in district $\mathrm{i}$, in year $\mathrm{t}$ & proportional \\
\hline avwage & average nominal monthly wage in district $\mathrm{i}$, in year $\mathrm{t}$ & continuous \\
\hline
\end{tabular}

Source: own processing

Our analysis will therefore be based on multi-dimensional data, while we will use a panel regression analysis to examine the relationship between the emergence of small and medium-sized enterprises in Slovakia and production, or changes in the distribution of educated human capital. Panel analysis is a statistical method that is widely used in the social sciences, medicine, and econometrics to analyse multidimensional panel data that includes (in the case of strongly balanced panels) the dimension of time and space (Maddala, 2001). The modelling will be based on the procedure described by Kohler and Kreuter (2009) and thus we will proceed from the OLS model, test the problems of the model in post-estimation diagnostics and compare the suitability of the model with fixed and random effects. The general equation of the regression model can be written as follows:

$$
\mathrm{y}_{\mathrm{it}}=\beta 0+\beta 1^{*} \times 1_{\mathrm{it}}+\beta 2^{*} \times 2_{\mathrm{it}}+\ldots+\beta \mathrm{n}^{*} \times \mathrm{n}_{\mathrm{it}}+\varepsilon \mathrm{it}
$$

after substituting our variables, the theoretical model can be written as follows:

$\mathrm{SMEs}_{\mathrm{it}}=\mathrm{b} 0+\mathrm{b}^{*}$ imigeduc $_{\mathrm{it}}+\mathrm{b}^{*}$ numgrad $_{\mathrm{it}-1}+\mathrm{b}^{*}$ busservices $_{\mathrm{it}}+\mathrm{b} 4^{*}$ inov $_{\mathrm{it}}+\mathrm{b}^{*}$ incub $_{\mathrm{it}}$ $+\mathrm{b}^{*}{ }^{*}$ counselling $_{\mathrm{it}}+\mathrm{b} 7^{*}$ popdens $_{\mathrm{it}}+\mathrm{b} 8^{*}$ foreign $_{\mathrm{it}}+\mathrm{b}^{*}$ avwage $_{\mathrm{it}}+$ cit

The variable number of graduates in the region is time-shifted by one year, due to the assumption of its later effects. 


\section{Results}

The development of small and medium-sized enterprises is one of the main preconditions for sustainable economic growth of the country, given contribution of these ventures to the growth of competitiveness of national and regional economies, through their flexibility, innovation dynamics and knowledge production, increased resilience in times of macroeconomic fluctuations and significant contribution to employment growth in the conditions of any country.

Map 1 Changes in the spatial distribution of small and medium-sized companies in the Slovak Republic between 2008-2018
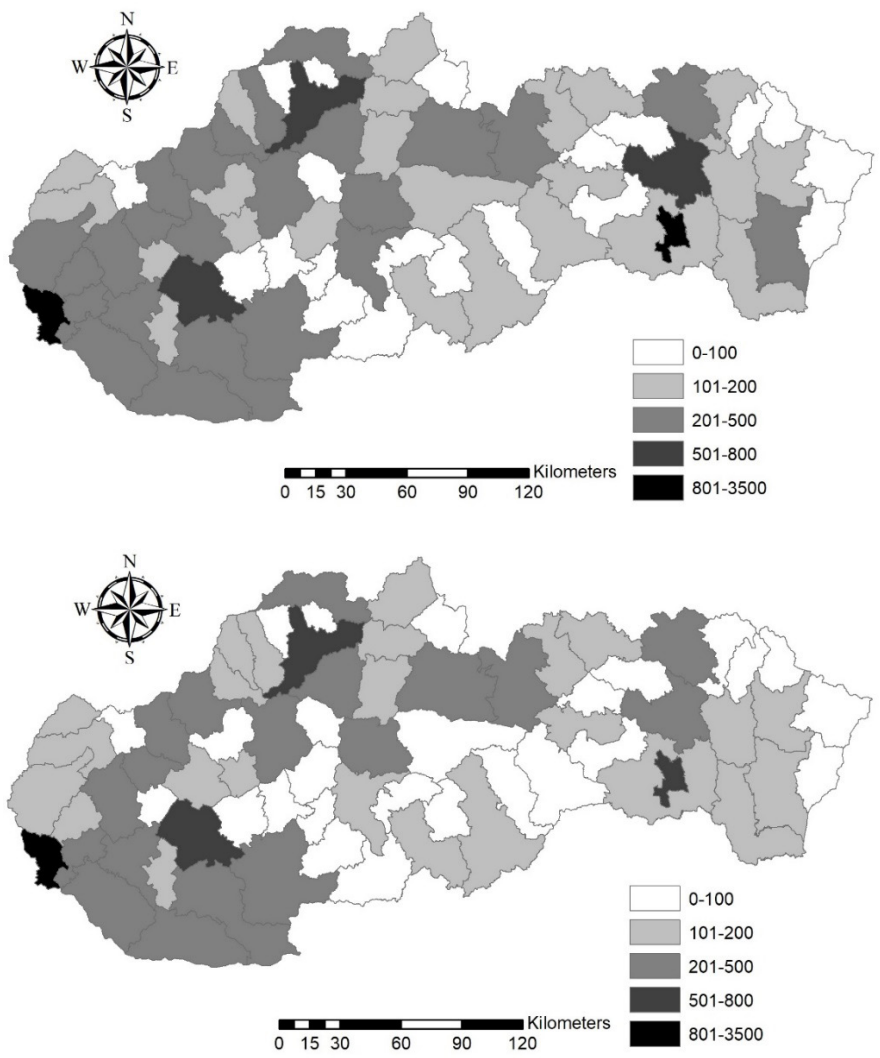

Source: own processing

The dynamics of small and medium-sized enterprises in the conditions of Slovakia will be investigated, which will be measured in the panel model by the number of small and medium-sized enterprises. We use the data of the Register of Institutional Units in the Slovak Republic (Elis database) and for the needs of our modelling 
we select from the database data on the number of small and medium enterprises of the size category from 10-250 employees. Between 2008 and 2015, the number of companies in this size category in Slovakia was growing steadily. There was a decline recorded in the growth of the dynamics of small and medium-sized enterprises between 2016 and 2018, while from 2019 their number was growing again (ŠÚSR, 2021). We present the spatial distribution of small and medium-sized companies in the first and last surveyed year (2008 and 2018) on map no. 1.

In the period before the temporary decline in the growth of the number of small and medium-sized enterprises, we could observe growth in SME dynamics especially in urbanized regions at the LAU1 spatial level, i.e. in districts of Bratislava and some surrounding districts of development poles - especially Senec and Dunajská Streda, further in the districts of the localization of regional seats, especially in the districts of Nitra, Žilina, Prešov and Košice. Despite the recorded decrease in the intensity of SMEs in the last 3 years examined, an increase in the number of SMEs was also recorded in the districts, with otherwise recorded very low values of the number of SMEs, such as Čadca, Kysucké Nové Mesto, or Námestovo.

The introduction of new technologies, processes and, more generally, new knowledge in small and medium-sized enterprises remains key to their growth and sustainability. In order for a company to take root in the digital economy, it must have a defined framework for producing and embracing innovation. Given the fact that human capital can be considered as one of the main factors influencing the absorption and production knowledge capacity of a company, it is in our interest to map how the availability of quality human capital affects the formation of SMEs. Due to the availability of secondary data, we will work with migration data - immigration of educated human capital to the LAU1 region and own production of educated human capital at the level of the LAU1 region - by the increase of university graduates.

On Map 2 we display the average number of immigrants with a university degree in the district between 2008-2018, which clearly reflects the ongoing process of urbanization and the growing concentration of educated human capital in cities, especially in the capital city of Bratislava, as the excluded rural regions are not sufficiently competitive in the context of available business opportunities, job offers in knowledge-intensive industries, the dynamics of knowledge-intensive entrepreneurship and available services, social and technical infrastructure in the region.

Between 2008 and 2018, up to 59 districts in Slovakia recorded a negative migration balance of the educated population. In total, up to 11,748 residents with a university degree migrated in the given period from these districts due to job opportunities and the possibility of starting a business to urbanized districts. Small immigration increases in the districts of south and north of central Slovakia, or districts of eastern Slovakia, except Košice and Prešov, are rather the result of normal migration for reasons such as job opportunities within the wider region or marriage. Otherwise, the values on Map 2 clearly show the trend of migration of the educated population to regional cities and the trend of deconcentration of the population from Bratislava to the adjacent districts, especially Senec, Malacky, Pezinok, or Dunajská Streda. The lack of human capital in rural and structurally disadvantaged regions contributes significantly to the problem of the inability to open new economic activities in rural areas or to achieve intelligent specialization of rural economies. 


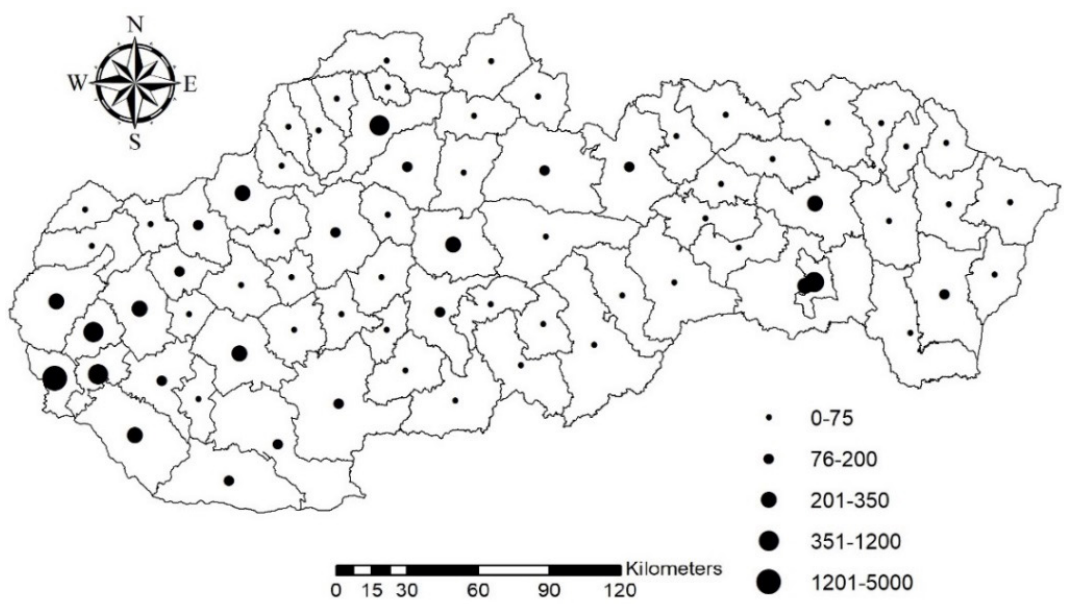

Source: own processing

New educated human capital was produced by universities in Slovakia in 18 districts during 2018, while the positive impact of graduates roll-out on regional economy in the district and surrounding districts (knowledge seepage) on business dynamics in knowledge-intensive industries was already demonstrated on case of Slovakia (Melichová et al., 2019). However, the volume of graduates produced has been declining significantly in recent years, mainly for demographic reasons. For comparison, in 2008 public higher education in Slovakia produced 34,899 graduates of I. and II. degree of full-time study programs and 18,958 graduates of I. and II. degree of external study programs, while in 2018 received a diploma from I. and II. degree of full-time study 30,293 and 3,585 external students', what is a strong decline.

The progressing concentration of educated human capital and the suction of human capital from rural to urban areas, together with the reduced volume of production of new educated human capital, could have a serious negative impact on the dynamics of business in Slovakia. Therefore, in the following parts of the results of the study we will evaluate the impact of intra-regional migration and the availability of graduates in districts on the dynamics of small and medium-sized enterprises emergence at the regional level. In table no. 2 , we provide an overview of the descriptive characteristics of the variables in the panel model. 
Table 2 Specification of variables in a panel model

\begin{tabular}{|c|c|c|c|c|c|}
\hline variable & observations & average & st.dev. & min & max \\
\hline SMEs & 792 & 252,2298 & 460,5318 & 12 & 4355 \\
\hline imigeduc & 792 & 180,4848 & 585,1693 & 0 & 5566 \\
\hline numgrad & 792 & 514,9773 & 1788,435 & 0 & 14485 \\
\hline busservices & 792 & 94,41919 & 270,1309 & 0 & 5042 \\
\hline inov & 792 & 1,308081 & 3,323066 & 0 & 42 \\
\hline incub & 792 & 0,210859 & 0,408176 & 0 & 1 \\
\hline counselling & 790 & 184,1266 & 759,0852 & 0 & 9603 \\
\hline popdens & 792 & 2312,633 & 801,4516 & 1065,142 & 6025,786 \\
\hline foreign & 792 & 0,035828 & 0,03372 & 0,005146 & 0,318761 \\
\hline avwage & 792 & 727,9661 & 140,7672 & 435,54 & 1400,6 \\
\hline
\end{tabular}

Source: own processing

Before clarifying the outlined relationships, which are the subject of research within our modelling, we want to briefly describe procedures used and diagnostics of the panel model. We progressed from standard OLS regression, which was used mainly for diagnostics, to panel models with fixed and random effects. Estimates of coefficients within the model with fixed effects will be decisive for us, given the statistically significant Hausman test.

At the bottom of table no. 3 with the results of individual models of SME formation in Slovakia between 2008 and 2018, we can also see other tests and post-estimation diagnostics, which was used to check the fulfilment of basic regression assumptions. Tests showed that the distribution of model errors showed a normal distribution, we also did not observe the problem of significant multicollinearity (average VIF 3.5 and VIF of individual variables - with max VIF 4.2 that meets the rule of thumb dictating maximal value of 5 to consider not relevant level of multicollinearity), but we noted the problem heteroscedasticity, therefore we used robust estimates for the coefficients of panel models. As part of the post-estimation diagnostics of panel models, we also identified the problem of cross-sectional dependencies, so we decided to create a model, marked in table no. 3 as no. IV., while for estimating the parameters of the coefficients we used Driscoll-Kraay standard errors. Data were standardized by z-scoring to allow for interpretation of coefficients.

Table 3 Results of individual models of SME formation in Slovakia between 2008-2018

\begin{tabular}{|l|c|c|c|c|}
\hline & I. & II. & III. & IV. \\
\hline variables & OLS & panel FE (robust) & panel RE (robust) & DKKRAY \\
\hline$z_{-}$SMEs & $0,3936^{* * *}$ & $0,1300^{* * *}$ & $0,4657^{* * *}$ & $0,3936^{* * *}$ \\
\hline & $(0,0585)$ & $(0,0259)$ & $(0,0149)$ & $(0,0264)$ \\
\hline$z_{-}$numgrad & $0,2492^{* * *}$ & $0,0858^{* * *}$ & $0,2312^{* * *}$ & $0,2492^{* * *}$ \\
\hline & $(0,0252)$ & $(0,0165)$ & $(0,0153)$ & $(0,0129)$ \\
\hline$z_{-}$busservices & 0,0873 & $0,0502^{* * *}$ & $0,0349 * * *$ & 0,0873 \\
\hline & $(0,0629)$ & $(0,0050)$ & $(0,0061)$ & $(0,0547)$ \\
\hline
\end{tabular}




\begin{tabular}{|c|c|c|c|c|}
\hline$z_{-}$inov & $0,0781 * * *$ & $0,0298 * * *$ & $0,0382 * * *$ & $0,0781 * * *$ \\
\hline & $(0,0181)$ & $(0,0049)$ & $(0,0061)$ & $(0,0158)$ \\
\hline \multirow[t]{2}{*}{$z_{-}$incub } & $0,0362 * * *$ & $-0,0060$ & 0,0184 & $0,0362 * * *$ \\
\hline & $(0,0068)$ & $(0,0120)$ & $(0,0107)$ & $(0,0029)$ \\
\hline \multirow[t]{2}{*}{$z_{-}$counselling } & $0,1596 * * *$ & $0,1009 * * *$ & $0,1153 * * *$ & $0,1596 * * *$ \\
\hline & $(0,0367)$ & $(0,0083)$ & $(0,0095)$ & $(0,0348)$ \\
\hline \multirow[t]{2}{*}{$z_{-}$popdens } & $0,0440 * * *$ & $-0,0074$ & $0,1005^{* * *}$ & $0,0440 * * *$ \\
\hline & $(0,0093)$ & $(0,0386)$ & $(0,0164)$ & $(0,0028)$ \\
\hline \multirow[t]{2}{*}{$z_{-}$avwage } & $-0,0157^{*}$ & $-0,0185 * * *$ & $-0,0076^{*}$ & $-0,0157 * * *$ \\
\hline & $(0,0070)$ & $(0,0040)$ & $(0,0044)$ & $(0,0044)$ \\
\hline \multirow[t]{2}{*}{ z_foreign } & $0,0789 * * *$ & $0,0163^{*}$ & $0,0411 * * *$ & $0,0789 * * *$ \\
\hline & $(0,0126)$ & $(0,0083)$ & $(0,0090)$ & $(0,0103)$ \\
\hline \multirow[t]{2}{*}{ _cons } & 0,0004 & 0,0011 & 0,0001 & 0,0004 \\
\hline & $(0,0065)$ & $(0,0023)$ & $(0,0138)$ & $(0,0085)$ \\
\hline $\begin{array}{l}\text { Number of } \\
\text { observations }\end{array}$ & 790 & 790 & 790 & 790 \\
\hline F & $2561,21 * * *$ & $90,75^{* * *}$ & & $47951,14 * * *$ \\
\hline Spatial Rho & & & $5390,92 * * *$ & \\
\hline$R-s q:$ & 0,9673 & & & 0,9673 \\
\hline Within & & 0.5353 & 0.4720 & \\
\hline Between & & 0.9707 & 0.9655 & \\
\hline Overall & & 0.9546 & 0.9606 & \\
\hline Hettest & $765,38 * * *$ & & & \\
\hline$V I F$ & 3,5 & & & \\
\hline Hausman test & & $277.95^{* * *}$ & & \\
\hline $\begin{array}{l}\text { Pearsan test for } \\
\text { cross-sect. dep. }\end{array}$ & & $76.56^{* * *}$ & & \\
\hline
\end{tabular}

Source: own processing

The results of the models confirm both hypothesis 1 and hypothesis 2 and proved that entrepreneurship formation is very sensitive on human capital distribution, both in terms of inter-regional migration and new educated human capital production. Even in the conditions of Slovakia, the development of small and medium-sized enterprises is significantly influenced by the access to educated human capital, what, however, can signalize future concerns of business development in rural areas of the country, given the pace of urbanization in Slovakia.

Several independent variables (especially population density per built-up area) indicate trend of the concentration of small and medium-sized enterprises in urbanized space. Thus, small and medium-sized enterprises are being formed to a much reduced extent in rural areas - also as a result of the emigration of educated human capital. The model clearly showed that with the increasing rate of immigration of inhabitants with tertiary education to the district, the dynamics of the formation of small and 
medium-sized enterprises is also increasing. By comparison, the effect of this variable, which mainly reflects the migration of educated people who already have some experiences (in most cases), is more pronounced, as is the positive impact of the production of new educated human capital at the district level. Inter-regional migration flows and the size of a particular labour market are strongly influencing the formation of SMEs, which also means that the retention of the educated population in less developed districts should become one of the key areas to support rural business development.

The dynamics of the formation of a small and medium-sized enterprises was influenced by several control variables. If we take into account panel models no. II. and III., in addition to the monitored human capital factors, access to knowledge appears to be key for the development of small and medium-sized enterprises - the most significant appears to be the impact of the availability of counselling for entrepreneurs and access to knowledge intensive business services for entrepreneurs. The significant need for access to new knowledge is also documented by the increased rate of formation of small and medium-sized enterprises in regions where innovation capacities, innovation traditions and access to legally protected knowledge exist. Small and medium-sized enterprises are attracted by agglomeration benefits and the presence of foreign investment in the region. However, even at the level of urbanized regions, a negative impact of certain externalities from the concentration of activities can be noted - in our case, it is a variable of the average nominal monthly wage. According to the results of the model, some small and medium-sized enterprises are interested in de-concentrating

from urbanized to rural regions due to cost reduction.

\section{Conclusion}

Small and medium-sized enterprises are the backbone of every spatial-level of economy. Support for small and medium-sized enterprises is relatively strongly enshrined in strategic documents - whether the partnership agreement 2021-2027, Vision and Development Strategy of Slovakia until 2030, economic and social development plans of self-governing regions, or other governmental plans. However, the form of support itself seems to be chaotic in the long run, provided by too large a number of instruments under the responsibility of both state, self-governing, financial, academic institutions (with a specific role of SBA), while in recent ESIF co-funded operational program "Research and innovation" provided just support over-oriented on baseline activities towards building of the knowledge-based economy.

The study points to the need to perceive the development of small and medium-sized enterprises in relation to access to smart capital, with specific regard to human capital with tertiary education. From this perspective, policy makers are able to support the formation of SMEs, mainly through interventions to improve access to high-quality intellectual, and specifically human capital, knowledge and available innovation. Improving the quality of human capital for SMEs can be achieved by strengthening the link between higher education and the needs of the labour market and dual education in secondary schools (Fürstenau et al. 2014; Assbring \& Nuur 2017), by introducing innovative tools (Zwolak, 2020) for linking universities with SMEs (such as industrial PhDs, innovation vouchers etc.), as roll-out of graduates in Slovakia has been declining for a long time and thus the need to increase its quality and retention capacity on regional level is growing (Hrivnák et al. 2019). Tools to improve access to knowledge should be based on the support of in-house research activities, technical start-ups and spin-off companies, enhancing partnerships and networking for collaboration on inno- 
vation activities, building clusters and knowledge hubs, or many other tools, which, however, should be integrated into framework allowing for complex strategic planning based on multi-source co-funding. We recommend to integrate measures to support small and medium-sized enterprises more visibly within the integrated territorial investments of the new programming period 2021-2027 using multi-source financing, while SMEs development priorities must be linked to the completion of knowledge infrastructure in rural areas. Retention of human capital in rural should be Slovakia's goal to slow down the urbanization process and growing inter-regional disparities.

\section{Bibliography}

1. Assbring, L., \& Nuur, C. (2017). What's in it for industry? A case study on collaborative doctoral education in Sweden. Industry and Higher Education, 31(3), pp. 184-194.

2. Åstebro, T., Bazzazian, N., \& Braguinsky, S. (2012). Startupsby recent university graduates and their faculty: Implica-tions for university entrepreneurship policy. Research Policy, 41(4), pp. 663-677.

3. Audretsch, D. B., Falck, O., Feldman, M. P., \& Heblich S. (2010). Local entrepreneurship in context. Regional Studies, 46(3), pp. 379-389.

4. Audretsch, D., \& Feldman, M. (2004). Chapter 61 - Knowledge Spillovers and the Geography of Innovation. Handbook of Regional and Urban Economics, 4, 2713-2739.

5. Badinger, H., \& Tondl, G. (2002). Trade, human capital and innovation: The engines of European regional growth in the 1990s. IEF, Working Paper, 42.

6. Barro, J. R. - Sala-I-Martin, X. (2004). Economic Growth. Cambridge: MIT Press. 557

7. Barro, J. R. (1991). Economic Growth in a Cross Section of Countries. Quarterly Journal of Economics, 106(2), pp. 407-443.

8. Barro, R. J. (1999). Human Capital and Growth in Cross-Country Regressions. Swedish Economic Policy Review, 6(2), pp. 237-277.

9. Bernanke, B. S., \& Gurkaynak, R. S. (2001). Is Growth Exogenous? Taking Mankiw, Romer and Weil Seriously. NBER, Working Paper, 8365.

10. Brassey T. (1872). Work and Wages. London: Bell \& Daldy, 296

11. Calcagnini, G., Favaretto, I., Giombini, G., Perugini, F., \& Rombaldoni, R. (2015). The role of universities in the location of innovative start-ups. The Journal of Technology Transfer, 41(4), pp. 670-693

12. Carmeli, A., \& Schaubroeck, J. (2005). How leveraging human resource capital with its competitive distinctiveness enhances the performance of commercial and public organizations. Human Resource Management, 44(4), pp. 391-412

13. Ciriaci, D. (2009). University quality, interregional brain drain and spatial inequality. The case of Italy. MPRA, Working paper, no. 30015.

14. Dahl, M. S., \& Sorenson, O. (2009). The embedded entrepreneur. European Management Review, 6(3), pp. 172-181.

15. Doms, M., Lewis, E., \& Robb, A. (2010). Local labour force education, new business characteristics, and firm performance. Journal of Urban Economics, 67(1), pp. 61-77.

16. Eigbiremolen, G. O., \& Anaduaka, U. S. (2014). Human capital development and economic growth: The Nigeria experience. International Journal of Academic Research in Business and Social Sciences, 4(4), 25-35.

17. Florax, R. (1992). The university: a regional booster? Beatty: Avebury. 346

18. Florax, R., \& Folmer, H. (1992). Specification and estimation of spatial linear regression models: Monte Carlo evaluation of pre-test estimators. Regional Science 
and Urban Economics, 22(3), pp. 405-432.

19. Frédéric, D., \& Marfouk, A. (2006). International Migration by Educational Attainment (1990-2000). In Ç. Özden, \& M. SCHIFF (Eds.), International Migration, Remittances, and the Brain Drain. New York: Palgrave Macmillian. Pp. 151-200.

20. Fürstenau B., Pilz M., \& Gonon P. (2014) The Dual System of Vocational Education and Training in Germany - What Can Be Learnt About Education for (Other) Professions. In S. Billett, C. Harteis, \& H. Gruber (Eds.), International Handbook of Research in Professional and Practice-based Learning (Springer International Handbooks of Education. Springer). Dordrecht: Springer, pp. 427-460.

21. Giannoccolo, P. (2006). The Brain Drain. A Survey of the Literature. SSRN, Working Paper, 2006-03-02

22. Grubel, H., \& Scott, A. (1966). The International Flow of Human Capital. American Economic Review, 56(2), pp. 268-274.

23. Hanson S. (2003). Geographical and feminist perspectives on entrepreneurship. Geographische Zeitschrift, 91(1), pp. 1-23.

24. Herbst, M., \& Rok, J. (2013). Mobility of human capital and its effect on regional economic development. Review of theory and empirical literature. MPRA, Working Paper, 45755.

25. Hrivnák, M., Melichová, K., Fáziková, M., Roháčiková, O. (2019). University graduates, knowledge spill-overs and localization of knowledge intensive ventures - case of post-socialistic country. Entrepreneurship and Sustainability, 7(1), 146-165.

26. Kaczmarczyk, P. (2010). Brains on the move? Recent migration of the highly-skilled from Poland and its consequences. In R. Black, G. Engbersen, M. Okólski, \& C. Panțĭru (Eds.), A Continent Moving West?: EU Enlargement and Labour Migration from Central and Eastern Europe. Amsterdam: Amsterdam university press, pp. 165-186.

27. Kohler, U., \& Kreuter, F. (2009). Data Analysis Using Stata. Texas: Stata Press, 388

28. Kucharčíková, A. (2011). Human Capital - Definitions and Approaches. Human Resources Management \& Ergonomics, 5(1), pp. 60-70

29. Kwok, V., \& Leland, H. (1982). An Economic Model of the Brain Drain. American Economic Review, 72(1), pp. 91-100.

30. Laperche, B., \& Liu, Z. (2013). SMEs and knowledge-capital formation in innovation networks: a review of literature. Journal of Innovation and Entrepreneurship, 2(1), pp. 1-16

31. Lesage J. P., \& Fischer, M. M. (2008). Spatial growth regressions: Model specification, estimation and interpretation. Spatial Economic Analysis, 3(3), pp. 275-304.

32. Liu, J. (2011). Human capital, migration and rural entrepreneurship in China. Indian Growth and Development Review, 4(2), 100-122.

33. Maddala, G. S. (2001). Introduction to Econometrics. New York: Wiley, 664

34. Mankiw, N. G., Romer, D., \& Weil, N. D. (1992). A contribution to the empirics of economic growth. Quarterly Journal of Economics, 107(2), pp 407-437.

35. Manzari, M., Kazemi, M., Nazemi, S., \& Pooya, A. (2012). Intellectual capital: Concepts, components and indicators: A literature review. Management Science Letters, 2(7), pp. 2255-2270

36. Martinez-Torres, M. R. (2006). A procedure to design a structural and measurement model of intellectual capital: An exploratory study. Information \& Management, 43(1), pp. 617-626

37. Melichová, K., Hrivnák, M., \& Fáziková, M. 2018. Univerzity ako determinant lokalizácie vzdelaného l'udského kapitálu. XXI. mezinárodní kolokvium 
o regionálních vědách. Sborník příspěvků. Brno : Masarykova univerzita, 2018, 133-140

38. Naudé, W., Siegel, M., \& Marchand, K. (2017). Migration, entrepreneurship and development: critical questions. IZA J Migration, 6(5), pp. 1-16.

39. Ogunleye, O. O., Owolabi, O. A., Sanyaolu, O. A., \& Lawal, O. O. (2017). Human Capital Development and Economic Growth in Nigeria. Journal of Business Management, 3(8), 17-37.

40. Pelinescu, E. (2015). The Impact of Human Capital on Economic Growth. Procedia Economics and Finance, 22(1), pp. 184-190

41. Schultz, T. W. (1979). Investment in Entrepreneurial Ability. The Scandinavian Journal of Economics, 82(4), pp. 437-448

42. Sollow, M. R. (1956). A Contribution to the Theory of Economic Growth. The Quarterly Journal of Economics, 1(1), pp. 65-94.

43. Tai, W. S., \& Chen, C. T. (2009). A new evaluation model for intellectual capital based on computing with linguistic variable. Expert Systems with Applications, 36(1), pp. 3483-3488

44. Thomas, K. J. A., \& Inkpen C. (2013). Migration Dynamics, Entrepreneurship, and African Development: Lessons from Malawi. International Migration Review, 47(4), 844-873.

45. Varga, A. (1997). Regional economic effects of university research: A survey. . Regional Research Institute Publications and Working Paper, 161.

46. Wall, A. (2005). The measurement and management of intellectual capital in the public sector. Public Management Review, 7(2), pp. 289-303

47. Zhuravlev, P. V., Poltarykhin, A. L, Alkhimenko, O. N., \& Kuksova, O. D. (2018). Human capital and its efficiency in the knowledge economy: the role of continuing education. Revista ESPACIOS, 39(46), pp. 1-8

48. Zwolak, J. (2020). Econometric comparison of regression dependencies between production and its innovation expenditures in Polish industries. Acta Oeconomica Universitatis Selye, 9(1), pp. 87-96.

\section{Correspondence address:}

Ing. Michal Hrivnák, PhD., Department of Regional and Rural Development, Faculty of European Studies and Regional Development, Slovak University of Agriculture in Nitra, Tr. A. Hlinku 2, 94976 Nitra, Slovakia, xhrivnak@uniag.sk

Mgr. Peter Moritz, Department of Regional and Rural Development, Faculty of European Studies and Regional Development, Slovak University of Agriculture in Nitra, Tr. A. Hlinku 2, 94976 Nitra, Slovakia,xmoritz@uniag.sk 